\title{
Geomorphosite assessment and management in protected areas of Greece Case study of the Lesvos island - coastal geomorphosites
}

\section{Nickolas C. Zouros, Mytilene}

\section{Introduction: geomorphosites and geoparks}

The term geomorphosites is not broadly used in the international literature but it can be used to describe landforms that are of particular importance for the comprehension of Earth history, as well as being spatially delimited and scientifically clearly distinguishable from their surroundings (GRANDGIRARD 1997; REYNARD 2005). During the last decade, several synonyms have been used: geomorphological assets (Panizza \& Piacente 1993), geomorphological sites (HoOKE 1994), geomorphological geotopes (GRANDGIRARD 1997), and sites of geomorphological interest (RIvas et al. 1997). According to the broad definition proposed by PANIZZA (2001), geomorphosites are geomorphological landforms that have acquired a «scientific», «cultural/historical», «aesthetic» and/or «social/economic value» due to human perception or exploitation. According to a more restrictive definition, a geomorphosite is defined as a part of the Earth's surface that is of particular importance for the knowledge of Earth, climate and life history (REYNARD 2004). These sites can be single geomorphological objects or wider landscapes (ReYnaRd \& PANIzZa 2005).

Every geomorphosite is located within a particular landscape. Current landforms are the result of three evolutions, the history of rocks, the history of tectonic deformation and the history of landforms (REYNARD 2005).

The geopark concept was developed mainly in Europe in cooperation with UNESCO. Geoparks are nationally protected areas which include either a number of internationally important geological heritage sites (geosites and geomorphosites) at any scale, or a mosaic of geological entities of special scientific importance, rarity or beauty. These features are representative of the region's geological history and the events and processes that formed it. Geoparks have well-defined limits and comprise a large enough surface area to serve local economic and cultural development (EDER \& PATZAK 2004; Zouros 2004; UNESCO 2004).

\section{Geomorphosites in Greek protected areas}

Greece with its complex geological and geomorphological setting and evolution, the great variety in climatic conditions and the numerous islands and con- voluted coastline presents a great diversity of natural scenery. The abiotic diversity and the «mosaic» of micro-climatic types are reflected in the presence of a highly diverse flora and fauna and a great variety of ecosystems.

Since 1937, Greece has been identifying natural areas of specific ecological importance to be placed under special protection. Today, protected areas make up more than $20 \%$ of the total land surface and include 11 national parks, 2 national marine parks, 51 natural monuments, 11 Ramsar wetlands, 529 landscapes of natural beauty and 239 areas selected as «Sites of Community Importance» within the framework of the Natura 2000 Network, funded by the European Union.

Greece is primarily a mountainous country, with $70 \%$ of its territory covered by mountains ( 42 summits over $2000 \mathrm{~m}$ ). Its very long coastline boasts a plethora of peninsulas and islands.

The Hellenic orogen is composite in character, consisting of three orogenic belts: Cimmerian, Alpine and Mesogean (Mountrakis 2005). The Cimmerian internal belt was formed in pre-Late Jurassic times as a result of the northward drift of Cimmerian continental fragments from Gondwana towards Eurasia. The Rodope mountain range is the most prominent feature on this belt. The Alpine orogenic belt was created during Cretaceus-Tertiary times after the Neotethyan subduction beneath the Cimmerian-Eurasian plate and the collision of the Apulia with the great plate. The Pindos mountain range is the main feature of this belt. The Mesogean orogenic belt along the external Hellenic arc formed as a result of the Mesogean-African underplate moving beneath the Alpine-Eurasian plate in Miocene-Pliocene times and the exhumation of the Cretan-Southern Peloponnesus tectonic windows. During Alpine and Mesogean orogenic processes in Tertiary times, a southwest migration of successive compressional and extentional tectonic events took place, producing nape stacking and extensional exhumation of underplate rocks. From the Pliocene until recent times, the extentional processes continued in the broader Aegean area producing normal and strike-slip faults (Fig. 1).

As a consequence of this complex geological and geomorphological setting and evolution, the Hellenides boasts the presence of a high geodiversity, spectacular landscapes and a large number of geomorphosites. 


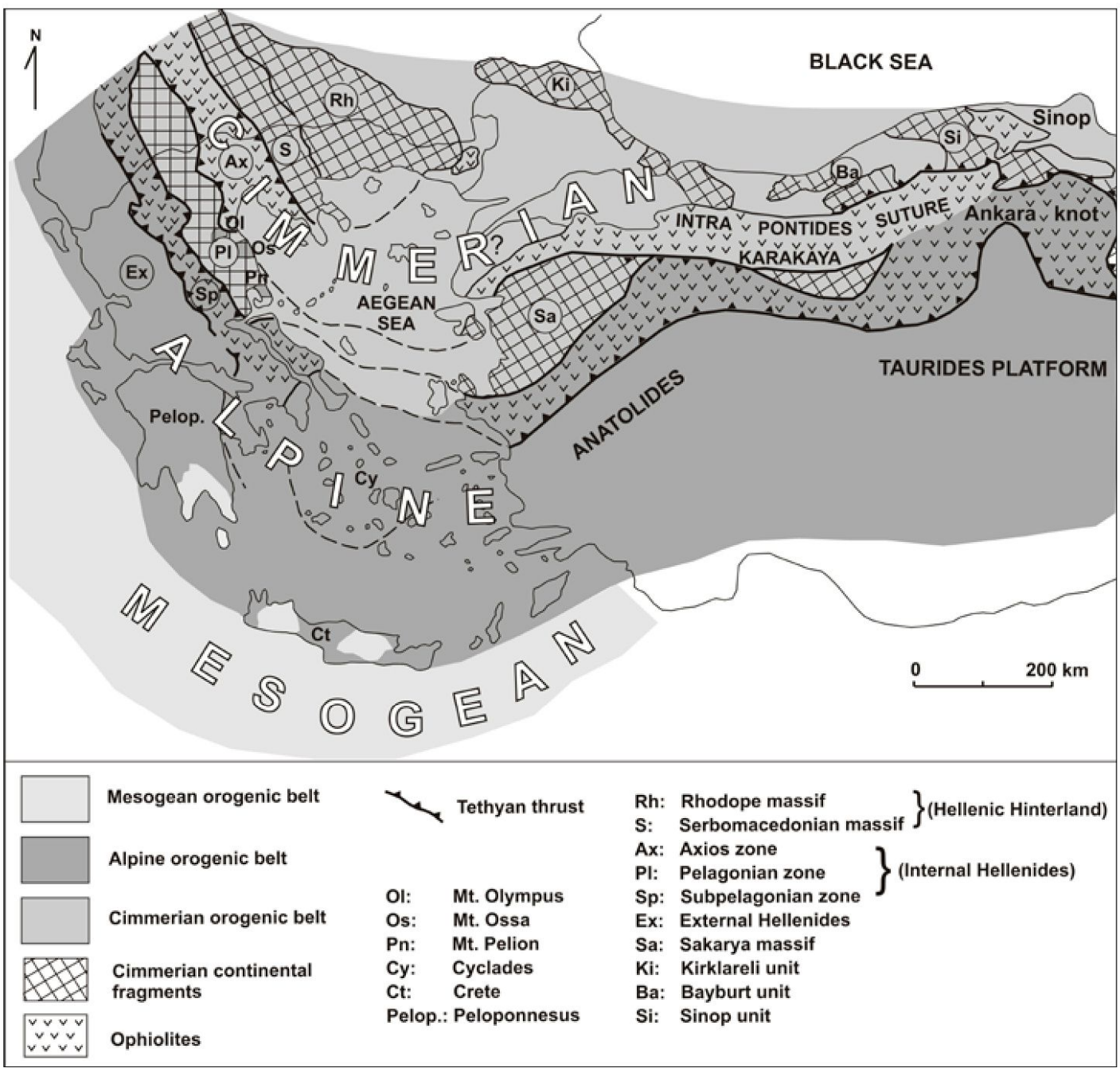

Fig. 1: Structural sketch-map showing the three orogenic belts of the Hellenic Orogen and their extension to the Minor Asia region. Cimmerian continental fragments and ophiolotic sutures after MounTRAKIs 1986 and 2006. Schematische Karte der drei tektonischen Gebiete der hellenischen Gebirgsbildung und ihrer Ausdehnung nach Kleinasien. Cimmerianische kontinentale Fragmente und ophiolitische Nahtstellen nach MounTRAKIS 1986 und 2006.

Carte structurale schématique montrant les trois domaines tectoniques liés à l'orogenèse hellénique et leur extension dans la région de l'Asie Mineure. Fragments continentaux cimmériens et sutures ophiolitiques selon MounTRAKIs 1986 et 2006.

Graphics: D. MountraKis

GraY (2004) defines geodiversity as the natural range of geological (rocks, minerals and fossils), geomorphological (landforms, processes) and soil features. Some of the most important geomorphosites, such as the Meteora, the Olympus mountain, the Samaria gorge in Crete, the Lavrion ancient mines included in the Sounion National Park, the Petrified Forest of Lesvos, the Vicos and Aoos gorges in Epirus, the Diros caves in Peloponnesus and the Santorini volcanic caldera, are established attractions with thousands of visitors each year.
Although the intrinsic value of geomorphosites for the natural environment is broadly accepted, their acknowledgment in Greece is connected mainly to either the conservation of habitats and ecosystems or to the protection of cultural sites. Geomorphosites have failed to gain attention autonomously as areas of value for conservation and management. Geomorphosites are neither mentioned in the management plan of the national parks, nor in their educational publications and promotional materials. Reliable geo- 
morphosite assessment methodologies could help to emphasise their value and importance as locations worthy of conservation, research and sustainable management.

In 1986, the Environmental Law 1650/86 made available for the first time in Greece a legal framework for the autonomous recognition of geological and geomorphological entities, even though it did not provide for their sustainable management. A wide range of new assessment approaches and initiatives followed the legal provision. The establishment of the first two geoparks in Greece, that is the Lesvos Petrified Forest Geopark in 2000 and the Psiloritis Geopark in Crete in 2001 (Zouros 2004), reflects the desire within Greece to preserve the rich geodiversity of the country. These initiatives have allowed experience to be gained in both geoconservation and the active involvement of the local communities in their earth heritage management.

\section{Geomorphosite assessment in Greek protected areas}

As mentioned above, geomorphosite assessment is a recent appearance. A survey of the appropriate literature indicates that the range of criteria used for this particular form of assessment is similar (GRANDGIRARD 1997; ReYnaRD 2004, 2005; CoRATZa \& Giusti 2005; Bruschi \& Cendrero 2005; Serrano \& GonzálezTrueba 2005; Pralong 2005). The methodology applied here draws on a series of six criteria used in the Aegean inventory of 317 geosites (Velitzelos et al. 2003; Zouros et al. 2004a; Zouros 2005). For each criterion, several indicators have been defined. As a quantitative approach to assessment was selected, each of the indicators is given a value between $0-10$ or $0-5$, with the highest possible score representing the highest value. The score of each criterion is thus the sum of its indicators. The quality of a geomorphosite can therefore be expressed by its total number of credits, with 100 being the highest score attainable.

In order to test the methodology at different scales, geomorphosite assessment was implemented at national park and monument level at the landscape scale and at geopark level (Lesvos Island Geopark) at the landform scale (Tab. 1).

The results of the assessment of eight major geomorphosites (or geomorphological landscapes) from protected areas in Greece (Fig. 2) are shown in Table 2 . This overview of the results allows comparison of attribute distribution and contribution to the overall score of the geomorphosites. Similarly, particular differences between sites with regards intrinsic value, «ecological» and «cultural value» and «management value» are made more visible.

As may be seen from the assessment, the percentage of high-scoring geomorphosites is significant, with high scores attained for «scientific» and «educational value», «ecological» and «cultural value», as well as «management value».

The same methodology could be used to evaluate other geomorphosites in national protected areas in Greece, thus making it a useful management tool.

In geoparks, the identification of the different facets of value of earth heritage sites is part of an holistic concept of protection, education and sustainable development. Assessment methodology, such as the one presented here, could help geopark management to quantify the values of their geomorphosites in relation to the whole geographical setting of the region.

\section{Geomorphosite assessment in the Lesvos Petrified Forest Geopark}

The Lesvos Petrified Forest Geopark is located on the western peninsula of Lesvos island in the northeastern Aegean sea. Due to its large accumulations of exposed fossilised tree trunks, it was declared a National Natural Monument in 1985 (Velitzelos \& Zouros 1998 $2000)$ and is considered to be home to important geomorphosites (Zouros 2005).

Aiming at protecting and efficiently managing the petrified forest, the Natural History Museum of the Lesvos Petrified Forest was founded in 1994. It is a non-profit organisation involved in the research, protection, promotion and rational utilization of the petrified forest and incorporates the management structure of the Lesvos Petrified Forest Geopark. This geopark includes a core zone $(15,000$ hectares of protected petrified forest) and a broad buffer zone (more than 20,000 hectares of the central volcanic terrain). Neogene volcanic rocks, which cover two thirds of the total surface of the Lesvos island (PE-PIPER \& PIPER 2002), are prominent features of the Lesvos Geopark.

Geomorphosites within the Lesvos Petrified Forest Geopark, apart from the fossil sites, include volcanic, tectonic, karstic, erosional (tafoni), coastal and fluvial landforms (Zounos 2005). The Lesvos Geopark integrates a range of sites and resources found in the broader region which include existing geological tourist attractions (the petrified forest visiting parks and the museum), a number of well exposed geomorphosites, particular landscapes, wetlands, sites of natural beauty and «ecological value», as well as cultural 


\begin{tabular}{|c|c|c|c|}
\hline & $\begin{array}{l}\text { Criteria and } \\
\text { Indicators }\end{array}$ & Assessment & Ranking \\
\hline $\mathbf{1}$ & \multicolumn{2}{|c|}{ scientific $\&$ educational value } & $40-0$ \\
\hline 1.1 & integrity & $\begin{array}{l}\text { depends on the degree to which a geomorphological structure or process } \\
\text { blends into the site and on its level of preservation }\end{array}$ & $10-0$ \\
\hline 1.2 & rarity & $\begin{array}{l}\text { depends on the number of similar sites at different levels (unique, } \\
\text { international, national, regional, local) }\end{array}$ & $10-0$ \\
\hline 1.3 & representativeness & $\begin{array}{l}\text { depends on the degree to which the site is typical of a certain } \\
\text { geomorphological process }\end{array}$ & $10-0$ \\
\hline 1.4 & exemplarity & $\begin{array}{l}\text { depends on the usefulness of the site for helping the general public to } \\
\text { understand a geomorphological structure or process }\end{array}$ & $10-0$ \\
\hline 2 & geodiversity & $\begin{array}{l}\text { number of geological and geomorphological phenomena that appear at each } \\
\text { site }\end{array}$ & 10-0 \\
\hline 3 & $\begin{array}{l}\text { ecological } \& \\
\text { aesthetic value }\end{array}$ & $\begin{array}{l}\text { characterization by international designation or by national or regional } \\
\text { legislation (WHS - natural world heritage site or MAB-biosphere reserve, } \\
\text { national park or national natural monument, natural park, regional park, } \\
\text { locally protected site) }\end{array}$ & 10-0 \\
\hline 4 & cultural value & $\begin{array}{l}\text { characterization by international designation or by national or regional } \\
\text { legislation (WHS - natural world heritage site, national cultural monument, } \\
\text { cultural landscape or landscape of outstanding aesthetic beauty, regional } \\
\text { monument, local monument) }\end{array}$ & 10-0 \\
\hline 5 & \multicolumn{2}{|c|}{ potential threats \& protection needs } & 10-0 \\
\hline 5.1 & legal protection & $\begin{array}{l}\text { the existing level of legal protection (international designation, national park } \\
\text { or monument, protected by national legislation, regional protection, poor } \\
\text { protection, no protection) }\end{array}$ & $5-0$ \\
\hline 5.2 & vulnerability & $\begin{array}{l}\text { presence and magnitude of potential threats (uncontrollable risk, strong } \\
\text { pressure, moderate risk, controlled risk, poor risk, no risk) }\end{array}$ & $5-0$ \\
\hline 6 & \multicolumn{2}{|l|}{ potential for use } & $20-0$ \\
\hline 6.1 & recognizability & $\begin{array}{l}\text { the level of recognition (international, national, regional, local, known only } \\
\text { by scientific community, unknown) }\end{array}$ & $5-0$ \\
\hline 6.2 & $\begin{array}{l}\text { geographical } \\
\text { distribution }\end{array}$ & $\begin{array}{l}\text { the percentage of the space occupied by the geomorphosites in relation to the } \\
\text { total surface of the protected area }\end{array}$ & $5-0$ \\
\hline 6.3 & accessibility & $\begin{array}{l}\text { the level of accessibility (by a road of regional or national importance, by } \\
\text { local road, by unsurfaced road, by foot path, with permission only, no access) }\end{array}$ & $5-0$ \\
\hline 6.4 & economic potential & $\begin{array}{l}\text { number of visitors per year (more than } 75.000 \text { visitors, more than } 50.000 \\
\text { visitors, more than } 20.000 \text { visitors, more than } 5.000 \text { visitors, less than } 5.000 \\
\text { visitors, no visitors) }\end{array}$ & $5-0$ \\
\hline
\end{tabular}

Tab. 1: Criteria and indicators of geomorphosite assessment methodology

Kriterien und Indikatoren der Bewertungsmethode

Critères et indicateurs inclus dans la méthode d'évaluation

monuments (the Sigri castle, the Ypsilou monastery, the Eressos acropolis), picturesque villages, traditional gastronomy and local products.

Several fossil sites were known to exist along the coast and on the beach but the actual importance of the coastal and the marine zone of the Lesvos Petrified Forest Geopark was only recognized when a research project carried out by the Museum delivered evidence of the presence of important fossil sites and erosional geomorphosites under the current sea level (Fig. 3).

In the marine zone, five main fossil sites were identified (Zouros et al. 2004b). Some of the fossils are standing, while others lie at the bottom of the sea at a depth of 4 to $5 \mathrm{~m}$. The diameters of the petrified tree trunks in the marine fossil sites vary between 0,5 to $3 \mathrm{~m}$.

In the coastal zone, several areas of special interest were identified, such as the Sigri and the Plaka Petrified Forest visiting parks, Faneromeni, Sarakina peninsula, Limena and Tsichliontas delta and the Nisiopi island.

The creation of the Sigri and Plaka Petrified Forest visiting parks was stimulated by its abundance of petrified tree trunks, the quality and variation of the fossils and the presence of impressive geomorphosites 


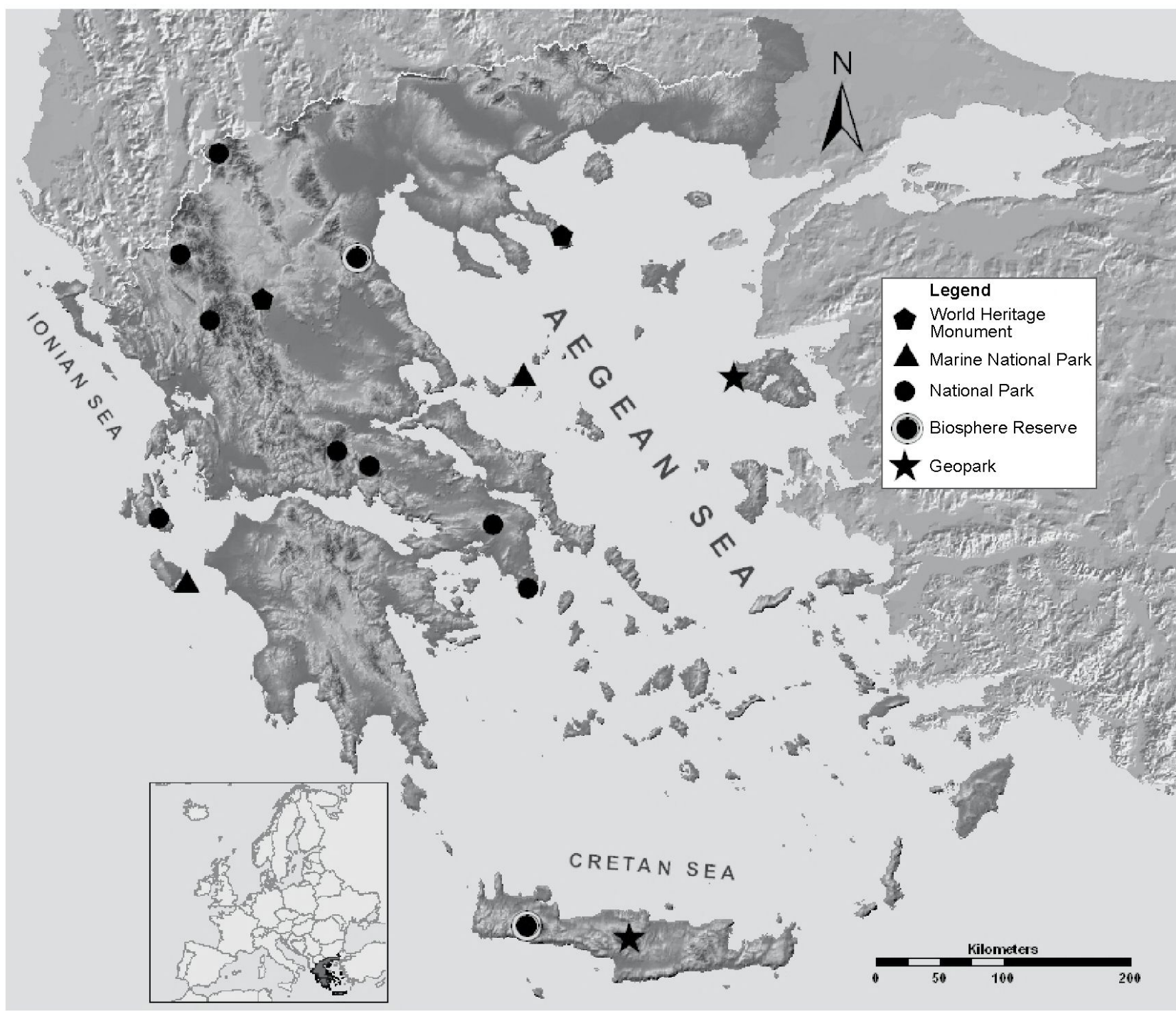

Fig. 2: National parks and other protected areas in Greece

Nationalparks und andere Naturschutzgebiete in Griechenland

Parcs nationaux et autres territoires protégés de Grèce

Source: Department of Geography, University of the Aegean; cartography: N. Zouros

(Photo 1). In both parts of the terrestrial zone of the Plaka Park, several clusters of petrified trees have been found and grouped in 45 different fossil sites (Fig. 4).

The Nisiopi Island Petrified Forest visiting area is less developed but it includes sites of high «scientific» and «educational value».

The impressive fossils and erosional landforms on the Sarakina peninsula also led to its declaration as a natural monument. Unfortunately, poor protection and management measures have been applied till now.
Apart from the fossil sites, the coastal area is characterized by unique volcanic, tectonic, erosional and coastal geosites. Along the coast, some spectacular tafoni structures may be found (Photo 2). Tafoni are characteristic cavernous weathering features which range in size and can lead to arch shaped entrances, concave inner walls, overhanging margins and fairly smooth gently sloping, debris-covered floors. They developed mainly on the andesitic boulders of the Sigri pyroclastics (Gumus \& Zouros).

In order to identify the potential use of the coastal and marine zone of the Lesvos Petrified Forest Geopark, 


\begin{tabular}{|c|c|c|c|c|c|c|c|c|c|}
\hline & Name & Meteora & $\begin{array}{l}\text { Lavrion } \\
\text { ancient } \\
\text { mines }\end{array}$ & $\begin{array}{l}\text { Olympus } \\
\text { Mnt. }\end{array}$ & $\begin{array}{l}\text { Samaria } \\
\text { gorge }\end{array}$ & $\begin{array}{l}\text { Lesvos } \\
\text { Petrified } \\
\text { Forest } \\
\end{array}$ & $\begin{array}{l}\text { Vicos- } \\
\text { Aoos } \\
\text { gorges } \\
\end{array}$ & $\begin{array}{l}\text { Diros } \\
\text { cave }\end{array}$ & $\begin{array}{l}\text { Santorin } \\
\text { caldera }\end{array}$ \\
\hline & Status & CM & NP/CM & NP & NP & $\mathbf{N M} / \mathbf{G}$ & NP & CM & LAB \\
\hline $\mathbf{1}$ & $\begin{array}{l}\text { scientific \& } \\
\text { educational value }\end{array}$ & & & & & & & & \\
\hline 1.1 & integrity & 10 & 9 & 10 & 10 & 8 & 10 & 10 & 8 \\
\hline 1.2 & rarity & 9 & 9 & 7 & 9 & 9 & 7 & 7 & 8 \\
\hline 1.3 & representativeness & 9 & 8 & 7 & 8 & 9 & 7 & 7 & 8 \\
\hline 1.4 & exemplarity & 9 & 8 & 8 & 8 & 7 & 6 & 6 & 9 \\
\hline 2 & geodiversity & 4 & 6 & 9 & 6 & 7 & 6 & 3 & 5 \\
\hline 3 & $\begin{array}{l}\text { ecological } \& \\
\text { aesthetic value }\end{array}$ & 10 & 8 & 10 & 10 & 8 & 8 & 6 & 6 \\
\hline 4 & cultural value & 10 & 8 & 8 & 6 & 6 & 6 & 8 & 6 \\
\hline 5 & $\begin{array}{l}\text { potential threats } \& \\
\text { protection needs }\end{array}$ & & & & & & & & \\
\hline 5.1 & legal protection & 5 & 4 & 4 & 4 & 4 & 4 & 4 & 3 \\
\hline 5.2 & vulnerability & 3 & 4 & 4 & 3 & 4 & 3 & 4 & 5 \\
\hline 6 & potential for use & & & & & & & & \\
\hline 6.1 & recognizability & 5 & 3 & 4 & 4 & 3 & 3 & 3 & 4 \\
\hline 6.2 & $\begin{array}{l}\text { geographical } \\
\text { distribution }\end{array}$ & 4 & 2 & 2 & 2 & 3 & 2 & 5 & 4 \\
\hline 6.3 & accessibility & 5 & 5 & 2 & 5 & 5 & 5 & 5 & 5 \\
\hline 6.4 & economic potential & 5 & 3 & 3 & 5 & 5 & 5 & 5 & 5 \\
\hline & TOTAL & 88 & 77 & 78 & 80 & 78 & 72 & 73 & 76 \\
\hline
\end{tabular}

NP=National Park, NM=National Natural Monument, G=Geopark, CM=Cultural Monument, LAB=Landscape of Outstanding Beauty

Tab. 2: Results of selected geomorphosite assessment in protected areas of Greece Bewertungsresultate geomorphologischer Geotope in ausgewählten Naturschutzgebieten Griechenlands Résultats de l'évaluation des géomorphosites sélectionnés dans les zones protégées grecques

fifteen geomorphosites of different sizes and from different categories were selected, classified and assessed. The above presented geomorphosite assessment methodology was applied on these specific geomorphosites of smaller scale (landforms) in order to create a new inventory for the Lesvos Geopark's coastal and marine zone and to assess the potential use of the sites.

As may be seen in the results presented in Table 3, geomorphosites of medium «scientific» and «educational value» dominate. Five sites appear to be particularly worthy of protection (S2, S4, S5, S7 and S15). The results emphasise the strong natural characteristics of the coastal zone of the Lesvos Geopark.

Although the «ecological value» of these sites is considered high, their «cultural value» or human use is low.
It is possible that due to the dominance of «desertification» processes in the region, the «cultural value» of the sites has not been recognized to its full potential.

Differences were also observed on-site between geomorphosites integrated in visiting parks and those in less frequented and unsupervised areas. Whereas the damage of sites in the first group was moderate, possibly due to protection through law enforcement the sites in the latter group suffered from vandalism. This appears especially the case for sites that can be reached by visitors using private boats (Tab. 3).

With regards potential for use (criteria 6), the percentage of low-scoring sites is significant. Only four sites score more than $50 \%$ (S2,S3, S4,S5). This result may be linked to the inaccessibility of the marine sites and the 


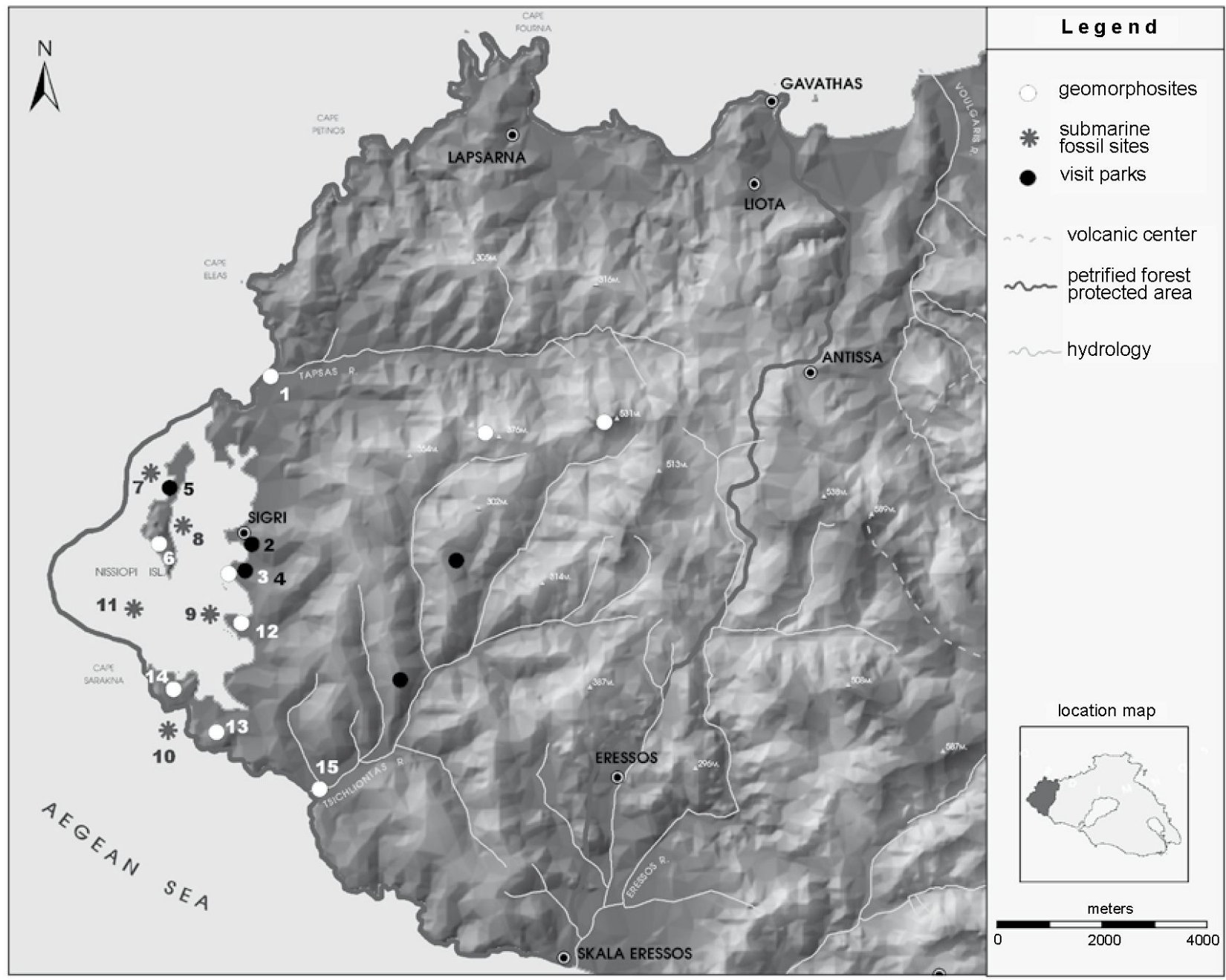

1=Faneromeni, 2=Sigri Park, 3=East Plaka Park, 4=West Plaka Park, 5=North Nisiopi site, 6=South Nisiopi site, 7=Skala Marine site (West Nissiopi coast), 8=Agios Georgios Marine site (East Nissiopi coast), 9=Bourouni Marine site, 10=Sarakina Marine site, 11=Kavalouros Marine site, 12=Limena site, 13=East Sarakina site 14=West Sarakina site, 15=Tsichliontas site

Fig. 3: Geomorphosites on the western coast of Lesvos island

Geomorphologische Geotope an der Westküste der Insel Lesbos

Géomorphosites de la côte occidentale de l'île de Lesbos

Source: Department of Geography, University of the Aegean; cartography: N. Zouros

poor accessibility of those areas not yet developed as visiting parks. Thus, much can still be done to improve their potential use for tourism and education.

Based on the results, the geomorphosites can be divided into two groups, the first group consisting of seven sites with high overall value (S2, S3, S4, S5, S6, S7, S14) and the second group with eight sites of medium value.

As a consequence of the identification of valuable geomorphosites, the management of the Lesvos Petrified Forest Geopark developed the idea of a West- ern Lesvos Marine Park which is to include the three coastal visiting parks and a marine route joining the marine fossil sites. The marine route has been designed to promote the volcanic origin of the coastal landscape and will take on the form of a guided tour. It is assumed that this measure will contribute towards improved protection and management of the sites.

This combination of a unique landscape and a rich ecosystem with geosites of high «scientific» and «educational value» is seen to be particularly interesting from the view point of tourism promotion. Not only will this park offer an alternative destination for tourists that 


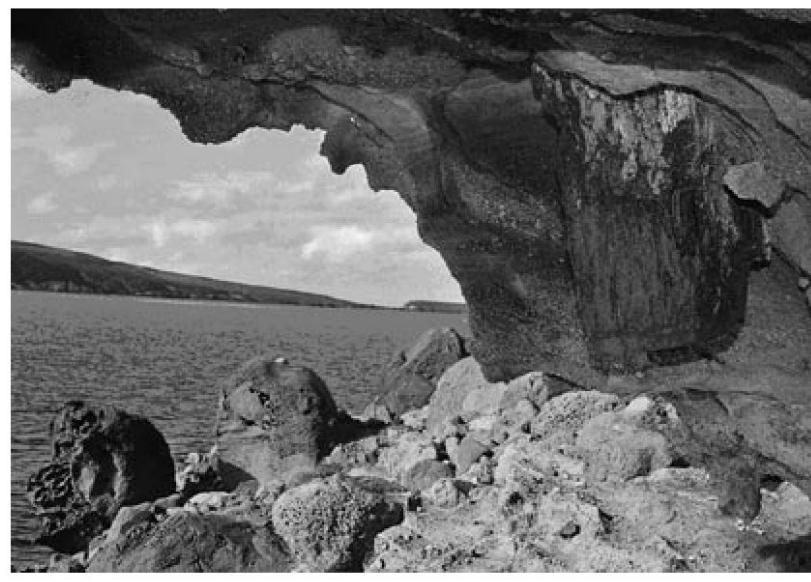

Photo 1: Petrified tree trunk (upper right) embedded in the Sigri pyroclastics is visible due to coastal erosion having destroyed the tree's root system. Tafoni structures (left) are typical of volcanic material to be found in Plaka Park.

Versteinerter Baumstamm (oben rechts) in den pyroklastischen Ablagerungen von Sigri. Der Stamm kam aufgrund dermarinen Erosion, die das Wurzelsystem zerstörte, zutage. Tafoni (links) sind im vulkanischen Material sichtbar.

Tronc pétrifié (en haut à droite) enfoncé dans les dépôts pyroclastiques de Sigri, visible en raison de l'érosion littorale ayant détruit son système de racines. Des tafonis (gauche) sont visibles dans le matériel volcanique.

Photo: N. Zouros

have already visited other fossil sites in the Lesvos Petrified Forest, it may also capture the interest of those who have little or no knowledge of the earth sciences.

\section{Geomorphosite management in the Lesvos Petrified Forest Geopark}

The Lesvos Petrified Forest Geopark applies certain management measures for the protection, conservation and promotion of all types of sites present in the territory. In 2000, a broad initiative for the identification and mapping of the various sites of interest was launched. The main product was the creation of the Lesvos Geopark inventory. This inventory fed into decisions made for the Geopark's management plan and led to the creation of five visiting parks with different foci regarding earth heritage, as well as to the creation of a network of pathways linking geomorphosites and other sites of interest on the terrestrial part of the Lesvos Geopark.

Site management in the Western Lesvos Marine Park has been defined using the results of the site assessment and includes a network of activities to monitor and safeguard the coastal and marine geomorphosites, such as regular maintenance (cleaning and marking), employment of rangers to patrol and monitor the condition of geosites, measures and protective installations against weathering and erosion, especially along the coast; conservation activities, description of geomorphosites with onsite information panels, leaflets and field guides, as well as the organisation of onsite activities that aim to raise public awareness of the importance of geodiversity.

Conservation of terrestrial fossil sites has been carried out and special shelters have been constructed for the more vulnerable sites. Small interventions were implemented where necessary to effectively conserve the fossil sites and to facilitate visitor access. These included the construction of protective low shelters, cobbling of pathways, installation of stone stairs and erection of stonewalls and wooden fences along the trails to guard the petrified trunks and protect them from run-off water and erosion.

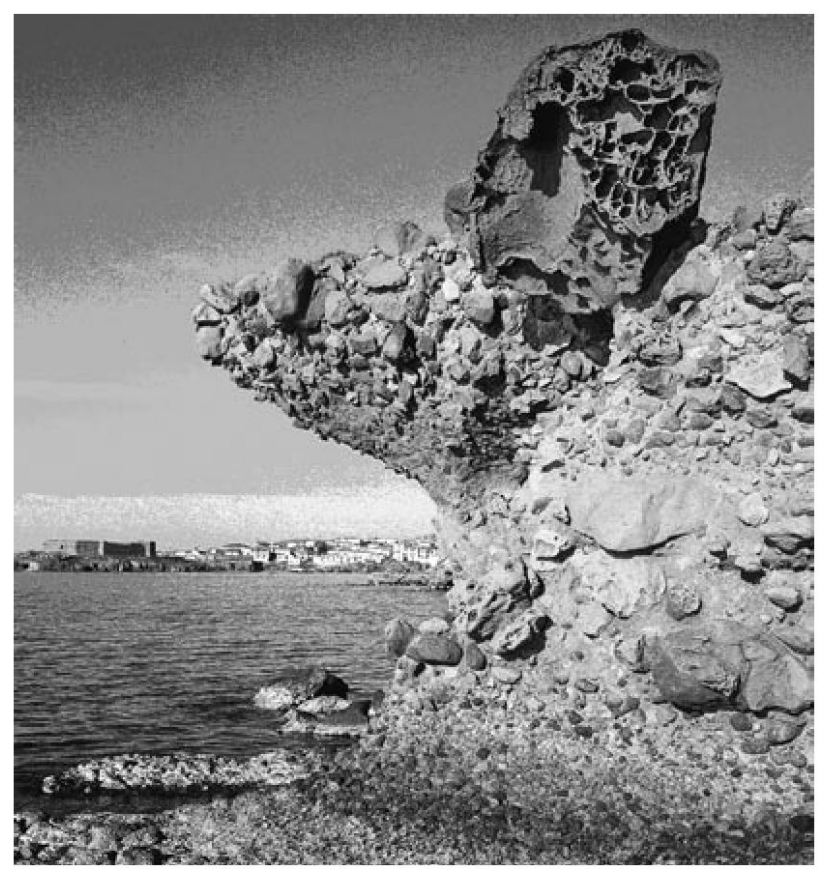

Photo 2: An impressive tafoni structure at the top of a wave cut notch developed on the upper coarse grained layer of Sigri pyroclastics in Plaka Park.

Eindrucksvolle Tafoni im Plaka-Park oberhalb eines Erosionseinschnittes in grobkörnigen pyroklastischen Ablagerungen von Sigri.

Impressionnants tafonis situés au sommet d'une entaille d'érosion développée dans les pyroclastes à granulométrie grossière de Sigri, dans le Parc de Plaka.

Photo: N. Zouros 


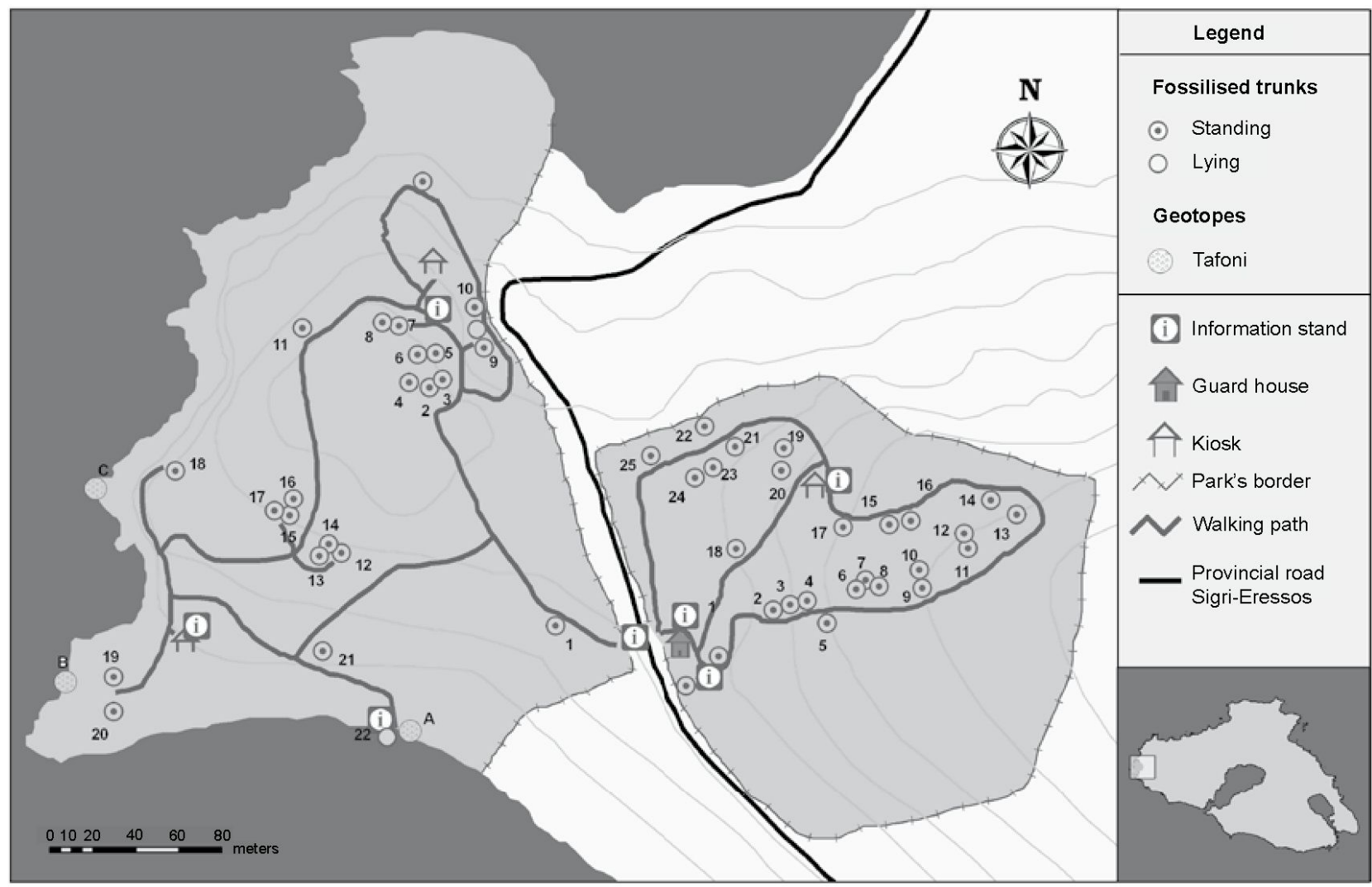

Fig. 4:The Plaka Park map with the excavated fossil sites and the main geomorphosites Karte des Plaka-Parks mit den fossilen Gebieten und den wichtigsten geomorphologischen Geotopen Carte du Parc de Plaka incluant les sites fossiles excavés et les principaux géomorphosites Source: Department of Geography, University of the Aegean; cartography: N. Zouros

Two of the most significant remaining threats to the coastal zone of the Lesvos Geopark are illegal collection of natural goods and coastal erosion. However, the negative consequences for the environment of increasing tourist numbers attracted to the coastal area and increasing direct abrasion of visitors walking past or standing on fossils may also be significant.

Further, the Museum offers educational programs for students to promote greater understanding of the importance of the geomorphosites of the coastal zone for the insight they offer into the geomorphological and geological processes that have formed the Aegean over the last 20 million years.

\section{Conclusions}

Geomorphosites have the potential to be acknowledged as natural and tourist resources with interesting economic benefits, especially if located in protected areas. The proposed methodology for assessment of geomorphosites located in protected areas was applied in Greek national parks and natural monuments in contexts in which geomorphology and geology had not been taken into consideration for conservation and management. The results of the assessments indicate that the examined large scale geomorphosites (landscapes) fulfil the required criteria to be characterized as major tourist attractions in terms of «scientific» and «educational value», aesthetic appeal and potential for use.

The same methodology was also applied at a smaller scale, focusing on the Lesvos Petrified Forest Geopark. Its aim was to evaluate specific geomorphosites (landforms). The results proved useful for the classification and characterization of the sites investigated.

Furthermore, the results fed into the proposal for the Western Lesvos Marine Park. The park has allowed a network of activities to be set up that ensure monitoring and safeguarding of the geomorphosites, the promotion of local identities, the creation of the necessary tourist infrastructure and the development of 


\begin{tabular}{|c|c|c|c|c|c|c|c|c|c|c|c|c|c|c|c|c|}
\hline & Site & S1 & $\mathbf{S 2}$ & S3 & S4 & S5 & S6 & S7 & S8 & S9 & $\mathbf{S 1 0}$ & S11 & S12 & S13 & S14 & S15 \\
\hline & Status & & & & $\mathbf{N M}$ & $\mathbf{N M}$ & & $\mathbf{N M}$ & & & & & & & NM & \\
\hline 1 & $\begin{array}{l}\text { scientific \& } \\
\text { educational value }\end{array}$ & & & & & & & & & & & & & & & \\
\hline 1.1 & integrity & 5 & 8 & 7 & 9 & 7 & 7 & 6 & 5 & 5 & 5 & 5 & 6 & 7 & 8 & 6 \\
\hline 1.2 & rarity & 5 & 8 & 7 & 8 & 7 & 5 & 7 & 5 & 5 & 6 & 5 & 6 & 6 & 8 & 5 \\
\hline 1.3 & representativeness & 5 & 7 & 6 & 8 & 6 & 6 & 6 & 5 & 6 & 5 & 5 & 6 & 6 & 7 & 5 \\
\hline 1.4 & exemplarity & 6 & 7 & 7 & 8 & 7 & 6 & 6 & 6 & 6 & 5 & 5 & 6 & 7 & 8 & 6 \\
\hline 2 & geodiversity & 3 & 5 & 4 & 6 & 6 & 7 & 6 & 3 & 2 & 2 & 2 & 3 & 4 & 5 & 2 \\
\hline 3 & $\begin{array}{l}\text { ecological \& } \\
\text { aesthetic value }\end{array}$ & 9 & 8 & 7 & 8 & 8 & 7 & 8 & 7 & 7 & 7 & 7 & 7 & 7 & 8 & 7 \\
\hline 4 & cultural value & 0 & 0 & 0 & 0 & 0 & 0 & 0 & 0 & 0 & 0 & 0 & 0 & 0 & 0 & 0 \\
\hline 5 & $\begin{array}{l}\text { potential threats \& } \\
\text { protection needs }\end{array}$ & & & & & & & & & & & & & & & \\
\hline 5.1 & legal protection & 3 & 4 & 3 & 4 & 4 & 3 & 4 & 3 & 3 & 3 & 3 & 3 & 3 & 4 & 3 \\
\hline 5.2 & vulnerability & 4 & 3 & 3 & 3 & 3 & 4 & 3 & 4 & 4 & 4 & 4 & 4 & 4 & 4 & 3 \\
\hline 6 & potential for use & & & & & & & & & & & & & & & \\
\hline 6.1 & recognizability & 1 & 3 & 3 & 3 & 3 & 1 & 1 & 1 & 1 & 1 & 1 & 1 & 1 & 1 & 1 \\
\hline 6.2 & $\begin{array}{l}\text { geographical } \\
\text { distribution }\end{array}$ & 2 & 3 & 3 & 3 & 3 & 2 & 2 & 2 & 2 & 2 & 2 & 2 & 2 & 2 & 2 \\
\hline 6.3 & accessibility & 3 & 5 & 3 & 3 & 2 & 2 & 1 & 1 & 1 & 1 & 1 & 3 & 2 & 2 & 3 \\
\hline \multirow[t]{2}{*}{6.4} & economic potential & 1 & 3 & 2 & 2 & 2 & 1 & 0 & 0 & 0 & 0 & 0 & 0 & 0 & 0 & 1 \\
\hline & TOTAL & 48 & 64 & 56 & 65 & 57 & 51 & 50 & 42 & 42 & 41 & 40 & 47 & 49 & 57 & 44 \\
\hline
\end{tabular}

1=Faneromeni, 2=Sigri Park, 3=East Plaka Park, 4=West Plaka Park, 5=North Nisiopi site, 6=South Nisiopi site, 7=Skala Marine site (West Nissiopi coast), 8=Agios Georgios Marine site (East Nissiopi coast), $9=$ Bourouni Marine site, 10=Sarakina Marine site, 11=Kavalouros Marine site, 12=Limena site, 13=East Sarakina site, 14=West Sarakina site, 15=Tsichliontas site; NM=National Natural Monument

Tab. 3: Results of geomorphosite assessment in the Lesvos Petrified Forest Geopark (coastal zone) Bewertungsresultate der geomorphologischen Geotope im Versteinerten Wald-Geopark von Lesbos Résultats de l'évaluation des géomorphosites dans le Géoparc de la Forêt pétrifiée de Lesbos

new local products and services, thereby encouraging local economic growth and creation of new opportunities for employment. Thus, it is expected that the new park will allow the most to be made of the relations that exist between earth heritage protection, nature conservation and sustainable local development.

\section{References}

Bruschi, V.M. \& A. Cendrero (2005): Geosite evaluation. Can we measure intangible values? - In: Il Quaternario 18, 1: 293-306.

Coratza, P. \& C. Giusti (2005): Methodological proposal for the assessment of the scientific quality of geomorphosites. - In: Il Quaternario 18, 1:307-313. Eder, W. \& M. PAtzaK (2004): Geoparks - geological attractions: a tool for public education, recreation and sustainable economic development. - In: Episodes 27, 3: $162-164$.

GrandGIRARD, V. (1997): Géomorphologie, protection de la nature et gestion du paysage. $-=$ Thèse de doctorat, Faculté des Sciences, Université de Fribourg. GraY, M. (2004): Geodiversity, valuing and conserving abiotic nature. - Chichester: Wiley \& Sons.

Gumus, E. \& N. Zouros: Cavernous weathering in Sigri area, Lesvos island, Greece. - In: Proceedings of the $6^{\text {th }}$ European Geoparks Meeting, Lesvos, 5-8 October 2005 (in press).

Hooke, J.M. (1994): Strategies for conserving and sustaining dynamic geomorphological sites. - In: O'Halloran, D. et al. (eds): Geological and landscape conservation. - London: Geological Society: 191-195. 
Mountrakis, D. (1986): The Pelagonian zone in Greece: a polyphase deformed fragment of the Cimmerian continent and its role in the geotectonic evolution of East Mediterranean. - In: Journal of geology 94: 335-347.

Mountrakis, D. (2006): Tertiary and Quaternary tectonics of Greece. - In: Dilek, Y. \& S. Pavlides (eds) Postcollisional tectonics and magmatism in the Mediterranean region and Asia. - Special paper 409, Boulder, Colo.: Geological Society of America: 125-136.

PANIzZA, M. (2001): Geomorphosites: concepts, methods and example of geomorphological survey. - In: Chinese science bulletin 46, Suppl. vol.: 4-6.

Panizza, M. \& S. Piacente (1993): Geomorphological assets evaluation. - In: Zeitschrift für Geomorphologie, N.F. Suppl. Bd. 87: 13-18.

Panizza, M. \& S. Piacente (2003): Geomorfologia culturale. - Bologna: Pitagora.

Pe-Piper G. \& D.J.W. Piper (2002): The igneous rocks of Greece. The anatomy of an orogen. - Berlin, Stuttgart: Gebrüder Borntraeger.

Pralong, J.-P. (2005): A method for assessing the tourist potential and use of geomorphological sites. - In: Géomorphologie. Relief, processus, environnement 3: 189-196.

Reynard, E. (2004): Geosites. - In:Goudie, A. (ed.): Encyclopedia of geomorphology. - London: Routledge: 440.

REYNARD, E. (2005): Géomorphosites et paysages. - In: Géomorphologie. Relief, processus, environnement 3: 181-188.

Reynard, E. \& M. Panizza (2005): Geomorphosites: définition, évaluation et cartographie. Une introduction. - In: Géomorphologie. Relief, processus, environnement $3: 177-180$.

Rivas, V., Rix, K., Frances, E., Cendrero, A. \& D. BRUNDSDEN (1997): Geomorphological indicators for environmental impact assessment: consumable and non-consumable geomorphological resources. - In: Geomorphology 18: 169-182.

Serrano, E. \& J.J. González-Trueba (2005): Assessment of geomorphosites in natural protected areas: the Picos de Europa National Park (Spain). - In: Géomorphologie. Formes, processus, environnement 3: 197-208.

UNESCO (2004): Network of national Geoparks seeking UNESCO assistance. - Paris: UNESCO, January 2004 , Internal document.

Velitzelos, E. \& N. Zouros (1998): New results on the petrified forest of Lesvos. - In: Bulletin of the Geological Society of Greece 32, 2: 133-142.

Velitzelos, E. \& N. Zouros (2000): The petrified forest of Lesvos. - Athens: Topio publications.

Velitzelos, E., Mountrakis, D., Zouros, N. \& N. SouLAKELIS (2003): Atlas of the geological monuments of the Aegean. - Athens: Ministry of the Aegean, Adam Editions (in Greek).

Zouros, N. (2004): The European geoparks network.
Geological heritage protection and local development. - In: Episodes 27, 3: 165-171.

Zouros, N. (2005): Assessment, protection and promotion of geomorphological and geological sites in the Aegean area, Greece. - In: Géomorphologie. Relief, processus, environnement 3: 227-234.

Zouros, N., Soulakelis, N., Mountrakis, D. \& E. VelitZELOS (2004a): Mapping, classification and assessment of geotopes in the Aegean. - In: Proceedings of the $7^{\text {th }}$ Hellenic Geographical Conference, Lesvos, 5 October 2004, Geographical Society of Greece 1: 527-534.

Zouros, N., Velitzelos, E., Valiakos, E. \& K. Ververis (2004b): Submarine petrified forest in Lesvos, Greece. - In: Proceedings of the $5^{\text {th }}$ International Symposium on Eastern Mediterranean Geology, Thessaloniki, 1419 April 2004: 437-440.

\section{Abstract: Geomorphosite assessment and manage- ment in protected areas of Greece. Case study of the Lesvos island - coastal geomorphosites}

This paper presents a methodology for assessment of geomorphosites located in protected areas. The methodological process involves definition of «geomorphological value» of all sites using six criteria: 1 ) «scientific» and «educational value»; 2) geodiversity; 3) «ecological» and «aesthetic value»; 4) «cultural value»; 5) potential threats and protection needs; and 6) potential for use. The assessment method was implemented in Greece on various geomorphosites at different scales: landscape scale (national parks and monuments) and landform scale (Lesvos Island Geopark). For this purpose, eight representative national parks and natural monuments were classified and assessed using the proposed methodology at a large scale. The same methodology was also used to evaluate 15 distinct geomorphosites found in the coastal zone of the Lesvos Petrified Forest Geopark. Here, geomorphosites of different sizes and categories were selected, classified and assessed. In order to protect the identified geomorphosites and ensure their proper management, the Natural History Museum of the Lesvos Petrified Forest, which is the management structure of the Lesvos Geopark, proposed the development of the Western Lesvos Marine Park. This park is to include the existing coastal visiting parks and a series of geomorphosites and marine fossil sites.

\section{Zusammenfassung: Bewertung und Management geo- morphologischer Geotope in Naturschutzgebieten Griechenlands. Fallstudie der Insel Lesbos - geomor- phologische Geotope im Küstengebiet}

Dieser Artikel stellt eine Bewertungsmethode für geomorphologische Geotope in Naturschutzgebieten vor. Anhand von sechs Kriterien konnte durch den Bewertungsprozess der geomorphologische Wert aller untersuchten Gebiete ermittelt werden: 1) der Wissenschaft- 
liche und der Didaktische Wert; 2) die Geodiversität; 3) der Ökologische und der Ästhetische Wert; 4) der Kulturelle Wert; 5) die möglichen Bedrohungen und die Schutzbedürfnisse; 6) die potentielle Nutzung. Die Methode wurde für die Bewertung von geomorphologischen Geotopen auf zwei Maßstabsebenen angewandt: dem Landschaftsmaßstab (Nationalparks und natürliche Sehenswürdigkeiten) und dem Maßstab der geologischen Form (Insel Lesbos-Geopark). Acht repräsentative Nationalparks und natürliche Sehenswürdigkeiten sowie 15 geomorphologische Geotope im Küstengebiet des Versteinerten Wald-Geoparks auf Lesbos wurden klassifiziert und bewertet. Um die ausgewählten geomorphologischen Geotope - zu denen der Versteinerte Wald-Geopark und marine fossile Gebiete gehören - zu schützen, hat das naturhistorische Museum des Versteinerten Waldes von Lesbos, das sich um die Leitung des Lesbos-Geoparks kümmert, den Marine-Park von West Lesbos gegründet. Der jetzige Park setzt sich aus einigen geomorphologischen Geotopen und submarinen Fossilgebieten zusammen.

\section{Résumé: Evaluation et gestion des géomorphosites dans les zones protégées grecques. Le cas des géo- morphosites côtiers de l'île de Lesbos}

Cet article présente une méthode d'évaluation des géomorphosites situés dans des zones protégées. Le processus d'évaluation a permis de donner une valeur géomorphologique à tous les sites étudiés sur la base de six critères: 1) la valeur scientifique et éducative;2) la géodiversité; 3) la valeur écologique et esthétique;4) la valeur culturelle; 5) les dommages potentiels et les besoins en termes de protection;6) le potentiel d'utili- sation. La méthode proposée a été utilisée pour l'évaluation de géomorphosites à l'échelle du paysage (les parcs nationaux et monuments naturels) et à l'échelle de la forme géomorphologique (le Géoparc de l'île de Lesbos). Huit parcs nationaux et monuments naturels représentatifs ainsi que quinze géomorphosites situés dans la zone côtière du Géoparc de la Forêt pétrifiée de Lesbos ont été classifiés et évalués. En vue de protéger et de gérer les géomorphosites identifiés, qui incluent la Forêt pétrifiée de Lesbos et certains sites fossiles marins, le Musée d'Histoire naturelle de la Forêt pétrifiée de Lesbos a créé le Parc marin de Lesbos occidental.

Nickolas Zouros, Assistant Professor in Physical Geography, Applied Geomorphology and Environmental Geology Lab., Department of Geography, University of the Aegean, GR-81100 Mytilene, Greece.

e-mail:nzour@aegean.gr

\section{Manuskripteingang/received/manuscrit entré le 15.3.2007}

Annahme zum Druck/accepted for publication/accepté pour limpression: 2.10 .2007 